Analitika: Jurnal Magister Psikologi UMA, Vol. 12 (2) Desember (2020)

ISSN: 2085-6601 (Print), ISSN: 2502-4590 (Online)

DOI: http://doi.org/10.31289/analitika.v12i2.3382

\title{
ANALITIKA
}

Jurnal Magister Psikologi UMA

Available online http://ojs.uma.ac.id/index.php/analitika

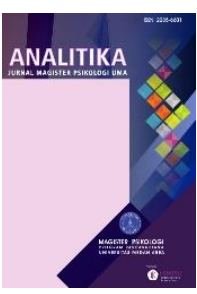

\section{Identifikasi Faktor Risiko, Dampak dan Intervensi Kecemasan Menghadapi Persalinan pada Ibu Hamil Trimester Ketiga}

\section{Identification of Risk Factors, Impacts and Anxiety Interventions Facing Childbirth in Third Trimester Pregnant Women}

\author{
Irma Isnaini*, Elli Nur Hayati \& Khoiruddin Bashori \\ Program Studi Magister Psikologi Profesi, Fakultas Psikologi, Universitas Ahmad Dahlan, \\ Indonesia
}

Diterima: 20 Januari 2020, disetujui: 17 Desember 2020, dipublish: 30 Desember 2020

*Corresponding author: E-mail: isnainirma@gmail.com

\begin{abstract}
Abstrak
Tinjauan ini bertujuan untuk menyelidiki kecemasan ibu menghadapi persalinan, dan mendeskripsikan faktor risiko, dampak buruk yang ditimbulkan, serta menyelidiki intervensi yang dapat digunakan untuk mengurangi kecemasan. Kecemasan menghadapi persalinan penting untuk dikaji, karena kecemasan yang berlebihan selama kehamilan dapat menimbulkan efek buruk baik bagi ibu maupun bayinya. Metode tinjauan literatur digunakan untuk mengumpulkan materi yang relevan tentang topik ini. Review literatur ini menemukan bahwa faktor usia dan paritas menjadi faktor risiko yang utama. Kecemasan yang berlebihan selama kehamilan dapat mengakibatkan stres dan depresi. Ibu yang memiliki kecemasan berlebihan cenderung melahirkan bayi prematur serta memiliki gangguan dalam pertumbuhan dan perkembangannya. Secara umum, musik, Al-Qur'an dan relaksasi dapat menjadi intervensi dalam mengatasi kecemasan tersebut.

Kata kunci: Kecemasan Persalinan; Ibu Hamil Trimester Ketiga
\end{abstract}

\section{Abstract}

This review aims to investigate maternal anxiety facing childbirth, and describe risk factors, adverse effects and investigate interventions that can be used to reduce anxiety. Anxiety facing childbirth is important to study, because excessive anxiety during pregnancy can cause adverse effects both for mother and baby. A literature review method was employed to gather relevant material on this topic. This literature review found that age and parity were the main risk factors. Excessive anxiety during pregnancy can lead stress and depression. Mothers who have excessive anxiety are more likely to give birth to premature babies and have a disruption in their growth and development. In general, music, Al-Qu'ran dan relaxation can be interventions in overcoming this anxiety.

Keywords: Childbirth Anxiety; Third Trimester Pregnant Women

How to Cite: Isnaini, I., Elli, N.H., \& Khoiruddin, B. (2020). Identifikasi Faktor Risiko, Dampak dan Intervensi Kecemasan Menghadapi Persalinan pada Ibu Hamil Trimester Ketiga. Analitika: Jurnal Magister Psikologi UMA, 12 (2): 112 - 122 


\section{PENDAHULUAN}

Di tahun 2017, sekitar 810 wanita meninggal karena sebab yang dapat dicegah terkait dengan kehamilan dan persalinan. Wilayah Afrika (Sahara) dan Asia Selatan menyumbang sekitar 86\% (254.000) dari perkiraan kematian ibu global pada tahun 2017. Afrika menyumbang sekitar dua pertiga (196.000) kematian ibu, sementara Asia Selatan menyumbang hampir seperlima (58.000) (World Health Organization, 2019). Menurut WHO kematian ibu adalah kematian selama kehamilan atau dalam periode 42 hari setelah berakhirnya kehamilan, akibat semua sebab yang terkait oleh kehamilan atau penanganannya, tetapi bukan disebabkan oleh kecelakaan/cedera (Kementerian Kesehatan RI, 2014).

Berdasarkan Survei Penduduk Antar Sensus (SUPAS) tahun 2015, angka kematian ibu di Indonesia menempati posisi 305 per 100 ribu kelahiran hidup (Achadi, 2019). Menilik capaian ini, angka kematian ibu di Indonesia masih cukup tinggi dibandingkan dengan negara-negara Asean yang sudah menempati posisi 40-60 per 100 ribu kelahiran hidup (Agung, 2019). Pada tahun 2017 angka kematian setelah melahirkan (neonatal) di Indonesia sebanyak 15 per seribu kelahiran hidup, dengan jumlah tersebut Indonesia menempati urutan ke sepuluh sebagai negara dengan angka kematian neonatal tertinggi di dunia (Utami, 2018).

Menurut World Health Organization (2019) kematian pada ibu disebabkan oleh komplikasi utama seperti perdarahan, infeksi, tekanan darah tinggi selama kehamilan, komplikasi dari persalinan, dan aborsi tidak aman. Berdasarkan data WHO, hampir $75 \%$ komplikasi utama yang menyebabkan kematian ibu salah satunya adalah tekanan darah tinggi selama kehamilan (pre-eklampsia dan eklampsia). Hasil penelitian menunjukkan sebanyak $52,7 \%$ ibu hamil yang mempunyai tingkat kecemasan sedang mengalami hipertensi, sedangkan $57,8 \%$ ibu hamil yang mempunyai tingkat kecemasan tinggi mengalami pre-eklampsia (Triasani \& Hikmawati, 2016).

Tingkat kecemasan sangat berpengaruh terhadap kesejahteraan ibu hamil maupun janin yang ada di dalam kandungan. Tingkat kecemasan yang rendah pada ibu hamil dapat mengurangi komplikasi yang ditimbulkan sehingga secara tidak langsung dapat mengurangi angka kematian ibu dan bayi, sedangkan tingkat kecemasan yang tinggi dapat memperberat komplikasi angka kematian ibu dan bayi (Siallagan \& Lestari, 2018). Bagi wanita, kecemasan dapat terjadi sewaktu proses kehamilan, karena saat hamil wanita akan mengalami perubahan fungsi fisik dan psikis dimana proses penyesuaian terhadap kondisi tersebut kemudian menimbulkan kecemasan. Selain itu, persalinan juga dapat menjadi pengalaman yang menyenangkan bahkan menegangkan bagi seorang wanita. (Kartono, 2007) menyatakan bahwa tingkat kecemasan ibu semakin akut dan intensif pada minggu terakhir usia kehamilan seiring dengan mendekatnya kelahiran bayi.

Kecemasan terbukti menjadi gangguan mental yang sering terjadi pada wanita hamil, diantaranya lebih banyak hadir pada trimester ketiga kehamilan (Silva, Nogueira, Clapis, \& Leite, 2017). Tingkat kecemasan yang lebih tinggi pada 
trimester ketiga kehamilan mungkin terkait dengan kedekatan persalinan yang dipersepsikan oleh sebagian ibu hamil sebagai momen-momen rentan serta mampu memicu perasaan takut (Silva et al., 2017).

Kecemasan juga disebabkan karena ibu memikirkan hal-hal yang berkaitan dengan persalinan yang berdampak pada munculnya perasaan tegang, bahkan berdebar-debar dan sensitif ketika memikirkan proses persalinan (Maimunah, 2009). Proses persalinan yang tidak mudah terkadang membuat ibu menjadi lebih gugup dan cemas mendekati waktu persalinan. Perubahan psikologis pada ibu trimester ketiga terkesan lebih kompleks dan meningkat kembali dibanding trimester sebelumnya, dan keadaan tersebut tidak lain dikarenakan kondisi kehamilan yang semakin membesar. Ibu hamil yang tidak mempunyai persiapan untuk melahirkan akan lebih cemas dan memperlihatkan ketakutan dalam suatu perilaku diam hingga menangis (Janiwarty \& Pieter, 2012).

Tujuan penelitian ini adalah untuk mendeskripsikan kecemasan pada ibu hamil dalam menghadapi persalinan, serta mendeksripsikan faktor-faktor yang menyebabkan kecemasan selama kehamilan, dampak yang ditimbulkan dan intervensi yang dapat dilakukan untuk mengurangi kecemasan selama kehamilan melalui studi literatur dari hasil penelitianpenelitian sebelumnya.

\section{METODE PENELITIAN}

Peneliti menggunakan tinjauan literatur dengan teknik summarize. Summarize merupakan teknik tinjauan literatur yang isinya berupaya untuk merangkum topik yang diteliti. Penelitian ini dilakukan dengan mengumpulkan berbagai materi yang relevan dengan topik. Pencarian literatur didasarkan dengan berbagai sumber, diantaranya jurnal penelitian, artikel ilmiah, prosiding dan buku.

Pencarian literatur selain dari sumber buku dilakukan secara online melalui empat database, yaitu Science Direct (sciencediret.com), Elsevier (elsevier.com), Google Scholar (scholar.google.co.id), dan Neliti (neliti.com). Pencarian literatur dilakukan selama empat minggu mulai dari 22 September-19 Oktober 2019. Kata kunci yang digunakan dalam pencarian literatur adalah "kecemasan/anxiety", "kehamilan/ pregnancy"," trimester ketiga/third trimester" dan "persalinan/childbirth".

Pada penelitian ini kriteria pemilihan literatur yang digunakan membahas mengenai kecemasan menghadapi persalinan, faktor-faktor yang dapat mempengaruhi kecemasan menghadapi persalinan, serta dampak dan intervensi kecemasan menghadapi persalinan.

\section{HASIL DAN PEMBAHASAN}

Kecemasan adalah keadaan emosional dengan ciri keterangsangan fisiologis, perasaan tegang yang tidak menyenangkan dan perasaan khawatir bahwa sesuatu yang buruk akan segera terjadi (Nevid, Rathus \& Greene, 2018). Pada ibu hamil, kecemasan menghadapi persalinan merupakan kecemasan yang umum dirasakan oleh ibu pada trimester ketiga (Bobak, Lowdermilk \& Jansen, 2005). Pada trimester ketiga, ada peningkatan 
untuk gejala kecemasan bila dibandingkan dengan trimester kedua. Peningkatan ini terjadi dikarenakan waktu persalinan semakin dekat yang memunculkan perasaan takut serta ibu membutuhkan lebih banyak persiapan sehingga kecemasan pun semakin meningkat (Teixeira, Figueiredo, Conde, Pacheco, \& Costa, 2009).

Kartono (2007) menjelaskan bahwa ada empat penyebab mengapa wanita mengalami kegelisahan atau ketakutan saat masa kehamilan, kegelisahan tersebut berkaitan dengan takut akan kematian, baik kematian dirinya sendiri maupun bayi yang akan dilahirkan, trauma kelahiran berupa ketakutan akan berpisahnya bayi dari rahim ibunya, perasaan bersalah/berdosa, dan ketakutan rill misalnya takut jika bayinya akan lahir cacat, takut kalau beban hidupnya akan semakin berat, takut kehilangan bayinya yang sering muncul sejak masa kehamilan sampai waktu melahirkan, serta takut jika bayinya akan bernasib buruk disebabkan oleh kesalahan ibu itu sendiri di masa silam. Jika krisis pada wanita hamil tidak dikelola dan dikendalikan dengan baik, itu akan menjadi krisis berkepanjangan dan meninggalkan banyak konsekuensi yang tidak diinginkan pada ibu dan bayinya (Glover, 2014).

Huliana (2001) menjelaskan bahwa pada setiap trimester kehamilan terdapat karakteristik kecemasan yang berbedabeda. Pada trimester pertama umumnya wanita hamil menunjukkan adanya rasa cemas, takut, dan panik akan mengalami keguguran kuat. Sedangkan pada trimester kedua umumnya kecemasan muncul karena wanita hamil mengkhawatirkan soal penampilan fisik dan merasa takut suami tidak akan mencintai dirinya lagi, dan pada trimester ketiga kecemasan muncul menjelang persalinan yang berkaitan dengan pertanyaan dan bayangan tentang proses persalinan dan kondisi bayi. Trimester pertama dan ketiga diidentifikasi sebagai periode risiko tinggi mengalami kecemasan, karena pada trimester ini tingkat kecemasan lebih tinggi jika dibandingkan dengan trimester kedua (Lee, Lam, Sze, Chong, et al., 2007). Berdasarkan hasil penelitian, gejala-gejala kecemasan dalam kehamilan dapat digambarkan mengikuti pola $U$, yaitu menjadi lebih tinggi pada trimester pertama, mengalami penurunan pada trimester kedua dan mengalami peningkatan kembali pada trimester ketiga (Teixeira et al., 2009).

Kecemasan pada ibu hamil dapat disebabkan oleh beberapa faktor. Wanita hamil trimester ketiga memiliki kecemasan yang lebih signifikan daripada trimester pertama dan kedua, selain itu ada korelasi yang signifikan secara statistik antara usia, tingkat pendidikan, status pekerjaan, catatan aborsi, hubungan pernikahan, dan rasa takut akan melahirkan (Nekoee \& Zarei, 2015). Beberapa penelitian menyatakan bahwa kecemasan ibu selama kehamilan terkait dengan faktor usia dan paritas (Zamriati, Hutagaol, \& Wowiling, 2013., Fazdria \& Harahap, 2016., Nurlailiyah, Machfoedz, \& Sari, 2016). Pada ibu hamil dengan usia kurang dari 20 tahun diindikasikan mengalami kecemasan berat karena kondisi fisik yang belum 100\% siap. Sedangkan setelah usia 35 tahun sebagian wanita digolongkan pada kehamilan beresiko tinggi terhadap kelainan bawaan dan adanya penyulit waktu persalinan. Dalam kurun usia tersebut, angka kematian ibu dan bayi meningkat sehingga akan 
meningkatkan kecemasan (Fazdria \& Harahap, 2016).

Menurut Bobak, et al (2005) paritas merujuk pada jumlah kehamilan yang menghasilkan janin hidup atau mati, bukan pada jumlah janin yang dilahirkan. Faktor paritas ikut mempengaruhi kecemasan dikarenakan wanita yang baru hamil untuk pertama kali (primigravida) memiliki kecemasan lebih tinggi dibandingkan dengan wanita yang telah hamil lebih dari satu kali (multigravida). Hal tersebut dikarenakan ibu primigravida belum mempunyai pengalaman tentang persalinan (Fazdria \& Harahap, 2016). Menurut hasil penelitian Hidayati (2014), ibu hamil dengan usia di atas 35 tahun yang sudah pernah melahirkan sebelumnya masih tetap dapat mengalami kecemasan. Kecemasan tersebut diantaranya disebabkan oleh bayangan ibu tentang proses persalinan, kekhawatiran ibu tentang kondisi kesehatan tubuhnya yang hamil di usia rawan, kekhawatiran akan kemungkinan terjadinya keguguran, bayi lahir tidak sempurna atau cacat, bayi lahir prematur dan melahirkan bayi kembar, serta faktor pengambilan keputusan, dan bayangan tentang proses persalinan sebelumnya.

Kecemasan pada ibu hamil juga disebabkan oleh beberapa faktor lain seperti pengalaman traumatis dan atau riwayat keguguran pada kehamilan sebelumnya (Zamriati et al., 2013., Azis \& Margaretha, 2017), tingkat pendidikan \& dukungan sosial dari keluarga \& suami (Rinata \& Andayani, 2018), pekerjaan \& pengetahuan (Nurlailiyah et al., 2016), status perkawinan (menikah/tidak menikah), riwayat penyakit mental yang positif, usia kehamilan, kehamilan yang tidak direncanakan, \& komorbiditas depresi (Fadzil, Balakrishnan, Razali, et al., 2013), serta hubungan dengan pasangan dan interaksi dengan sistem perawatan kesehatan (Rosario, Premji, Nyanza, Bouchal, \& Este, 2017).

Studi menemukan bahwa ada hubungan antara kecemasan prenatal dan depresi terhadap bayi yang dilahirkan (O'Connor, Heron, Golding, Beveridge, \& Glover, 2002., Austin, Hadzi-Pavlovic, Leader, Saint, \& Parker, 2005). Kecemasan dan depresi adalah komorbiditas yang sangat kuat dan sulit untuk menguraikan efek diantara keduanya. Tingkat kecemasan yang tinggi selama kehamilan dan stres memiliki dampak negatif atau efek buruk pada ibu dan bayi (Schetter \& Tanner, 2012., Ding, Wu, Xu et al., 2014., Brunton, 2013) yang dapat meningkatkan risiko depresi berat dan gejala kecemasan setelah melahirkan (Cookson, Granell, Joinson, Ben-Shlomo, \& Henderson, 2009) serta kehamilan dapat membuka atau memperburuk kecenderungan untuk mengalami depresi (Bahrami \& Bahrami, 2013).

Wanita yang memiliki kekhawatiran dan stres berat selama kehamilan lebih cenderung melahirkan bayi prematur. Bayi-bayi ini dapat mengalami beberapa masalah, seperti menyusu yang tidak teratur, kembung dan sakit perut, insomnia di malam hari, tangisan yang lama, dan kebutuhan mendesak untuk dipeluk (Martínez \& Castillo, 2016). Jika ibu mengalami depresi, kecemasan, atau stres saat kehamilan, anak akan lebih memiliki kemungkinan mengalami berbagai hasil perkembangan saraf yang merugikan daripada anak-anak lain dari ibu yang tidak mengalami depresi, 
cemas atau stres selama hamil (Glover, 2011).

Kecemasan ibu memiliki dampak yang signifikan pada berat lahir bayi (Ding et al., 2014., Brunton, 2013., Schetter \& Tanner, 2012). Stres prenatal dapat menyebabkan berat badan lahir rendah untuk usia kehamilan, persalinan lebih awal, hipertensi (Cardwell, 2013), dan perubahan hasil fisik seperti peningkatan risiko asma (Khashan, Wicks, Dalman, et al., 2012). Anak-anak yang lahir dari ibu yang mengalami kecemasan selama kehamilan, juga disertai dengan masalah emosional, gangguan hiperaktif, desentralisasi, dan gangguan dalam perkembangan kognitif (Glover, 2014., Tarabulsy et al., 2014). Selain itu dapat juga berdampak pada pertumbuhan dan perkembangan sistem saraf anak-anak. Masalah ini dikaitkan dengan konsekuensi perilaku negatif, seperti respon bayi terhadap suara normal dan standar dalam sembilan bulan pertama kehidupan bayi yang lebih mudah tersinggung dan gugup (van den Heuvel, Donkers, Winkler, Otte, \& Van den Bergh, 2013., \& van den Heuvel, Johannes, Henrichs, \& Van den Bergh, 2015). Bayi yang lahir dari ibu dengan kecemasan tinggi secara signifikan memiliki berat badan rendah, daripada bayi yang lahir dari ibu tanpa kecemasan (Hasanjanzadeh \& Faramarzi, 2017).

Penelitian lain menunjukkan hasil yang berbeda, bahwa gejala depresi antenatal dan/atau kecemasan tidak secara independen terkait dengan hasil kelahiran yang merugikan (Staneva, Morawska, Bogossian, \& Wittkowski, 2018), serta secara statistik tidak ada efek yang signifikan dari keadaan ibu antenatal dan kecemasan antenatal pada berat badan neonatal (Vujovic, Sovili, Plesinac, et al., 2019). Faktor yang paling kuat terkait dengan hasil kelahiran yang merugikan atau buruk adalah faktor biomedis, yang terkait dengan masalah fisiologis selama kehamilan, seperti infeksi, masalah dengan plasenta dan kanabis (Staneva et al., 2018).

Pada berbagai studi penelitian, telah dilakukan intervensi yang berguna untuk mengurangi kecemasan selama masa kehamilan, salah satunya yaitu dengan musik. Musik terbukti efektif untuk mengurangi kecemasan pada wanita hamil berisiko tinggi (Yang, Li, Zhu, et al., 2009., Shin \& Kim, 2011). Mendengarkan musik juga telah ditemukan mampu untuk mengurangi kortisol ibu dan skor keadaan kecemasan pada ibu hamil (Ventura, Gomes, \& Carreira, 2012). Tidak hanya musik, intrevensi lain dengan menggunakan Al-Quran juga menunjukkan hasil yang positif.

Mendengarkan suara Al-Qur'an, dengan atau tanpa terjemahan, efektif dalam mengurangi intensitas stres, kecemasan dan depresi selama kehamilan (Jabbari, Mirghafourvand, Sehhatie, \& Charandabi, 2017). Mendengarkan murottal Al-Quran dapat menurunkan kecemasan pada ibu bersalin primigravida (Handayani, Fajarsari, Asih, \& Rohmah, 2016., \& Karyati, 2016) serta terapi dengan murotal Al-Qur'an dapat menurunkan intensitas nyeri pada ibu bersalin dan dapat meningkatkan kadar $\beta$-Endorphin (Wahida, Nooryanto, \& Andarini, 2015).

Selain itu terdapat korelasi negatif yang sangat signifikan antara intensitas membaca Al-Qur'an dengan kecemasan ibu hamil, dimana semakin tinggi intensitas membaca Al-Qur'an maka semakin rendah kecemasan ibu hamil, dan sebaliknya 
(Untari \& Rohmah, 2016). Dalam hal ini terapi tadabur Al-Qur'an sebagai intervensi mampu untuk menurunkan kecemasan pada ibu hamil (Prapto, Nashori, \& Rumiani, 2015). Selain musik dan AlQuran, relaksasi juga telah terbukti meningkatkan indeks neurobehavior pada janin, seperti variabilitas detak jantung (DiPietro, Costigan, Nelson, Gurewitsch, \& Laudenslager, 2008).

Teknik relaksasi telah terbukti efektif dalam mengurangi nyeri persalinan, kegelisahan dan insomnia (Payne, 2005). Metode relaksasi efektif dalam mengurangi keadaan emosi negatif serta dapat meningkatkan tingkat kenyamaman emosional pada ibu hamil (Guszkowska, Sempolska, Zaremba, \& Langwald, 2013). Relaksasi juga efektif dalam mengurangi kecemasan dan meningkatkan perlekatan maternal pada ibu yang menggunakan fertilisasi in-vitro untuk mendapatkan kehamilan (Toosi, Akbarzadeh, \& Ghaemi, 2017). Terdapat juga hasil yang menyatakan bahwa relaksasi pernafasan dengan dzikir secara signifikan dapat mengurangi kecemasan pada ibu hamil dalam menghadapi persalinan pertama (Maimunah, A \& Retnowati, 2011).

\section{SIMPULAN}

Berdasarkan tinjauan literatur di atas, dapat disimpulkan bahwa kecemasan menghadapi persalinan merupakan kecemasan yang umum dirasakan oleh ibu hamil khususnya pada trimester ketiga. Hal ini mungkin terkait dengan kedekatan waktu persalinan yang memicu perasaan takut, gelisah, serta tegang tentang bayangan proses persalinan yang tidak mudah serta kondisi bayi dan ibu saat melahirkan kelak. Faktor risiko yang dapat mempengaruhi kecemasan pada ibu diantaranya usia, paritas, riwayat keguguran, pendidikan, dukungan sosial, status pernikahan, usia kehamilan, riwayat penyakit mental yang positif, kehamilan tidak direncanakan, komorbiditas depresi, hubungan dengan pasangan dan interaksi dengan sistem perawatan kesehatan. Namun, usia dan paritas menjadi faktor risiko utama yang dapat mempengaruhi kecemasan selama kehamilan maupun menghadapi persalinan. Sedangkan dampak dari kecemasan selama hamil yang tidak dapat diatasi dapat berpengaruh pada kondisi psikologis ibu yang rentan mengalami depresi dan gejala kecemasan setelah melahirkan. Ibu dengan kecemasan berat memiliki kecenderungan melahirkan bayi prematur, berat lahir bayi rendah, meningkatkan risiko asma, terganggunya proses pertumbuhan dan perkembangan, risiko gangguan perilaku dan perkembangan saraf yang merugikan. Namun gejala kecemasan tidak serta merta terkait dengan hasil kelahiran yang buruk, faktor utama yang paling mempengaruhi adalah faktor biomedis. Meskipun kecemasan tidak serta merta berpengaruh pada hasil lahir yang buruk, penting bagi ibu untuk dapat mengatasi kecemasan selama kehamilan. Berdasarkan tinjauan literatur, intervensi dengan menggunakan musik, Al-Qur'an maupun relaksasi dapat berguna untuk mengurangi kecemasan. Musik dapat mengurangi tingkat kortisol pada tubuh ibu dan kecemasan pada kehamilan berisiko tingg. Mendengarkan Al-Qur'an dapat menurunkan kecemasan ibu hamil maupun bersalin, mengurangi intensitas nyeri dan meningkatkan kadar endorphin. Relaksasi dapat mengurangi kecemasan selama kehamilan, mengurangi 
nyeri persalinan, perasaan gelisah dan meningkatkan tingkat kenyamanan emosional pada ibu. Penelitian ini berusaha mendeskripsikan gambaran kecemasan menghadapi persalinan pada trimester ketiga dan mengungkap faktor risiko, dampak serta intervensi untuk mengurangi kecemasan. Pada penelitian ini diungkap empat tujuan sekaligus yang membuat bahasan pada penelitian kurang detail karena kurang bisa memfokuskan diskusi pada satu hal. Penelitian selanjutnya diharapkan bisa membahas secara lebih mendalam mengenai kecemasan menghadapi persalinan dan membahas secara menyeluruh diantara faktor risiko, dampak maupun intervensi kecemasan menghadapi persalinan.

\section{DAFTAR PUSTAKA}

Achadi, E. L. (2019). Kematian Maternal dan Neonatal di Indonesia. Rapat Kerja Kesehatan Nasional Kementerian Kesehatan RI. Tangerang 13 Februari 2019.

Agung. (2019). AKI di Indonesia Masih Tinggi. Retrieved November 15, 2020, from https://ugm.ac.id/berita/17548-aki-diindonesia-masih-tinggi

Austin, M. P., Hadzi-Pavlovic, D., Leader, L., Saint, K., \& Parker, G. (2005). Maternal trait anxiety, depression and life event stress in pregnancy: Relationships with infant temperament. Early Human Development, 81(2), 183-190. https://doi.org/10.1016/j.earlhumdev.2004.07. 001

Azis, N. A. \& M. (2017). Strategi Coping terhadap Kecemasan pada Ibu Hamil dengan Riwayat Keguguran di Kehamilan Sebelumnya. 05(01), 144-157.

Bahrami, N \& Bahrami, S. (2013). Corelation between depression during pregnancy and delivery and newborn anthropometric indices. Koomesh Jurnal of Semnan University of Medical Sciences, 15(01), 39-45.

Bobak, I. M., Lowdermilk, D. L., \& J. (2005). Buku Ajar Keperawatan Maternitas Edisi 4. Jakarta: Penerbit Buku Kedokteran EGC.

Brunton, P. J. (2013). Effects of maternal exposure to social stress during pregnancy:
Consequences for mother and offspring. Reproduction, 146(5). https://doi.org/10.1530/REP-13-0258

Cardwell, M. S. (2013). Stress: pregnancy considerations. Obstetrical and Gynecological Survey, 68(02), 119-129. https://doi.org/10.1097/o1.pec.00o0526609.89 886.37

Cookson, H., Granell, R., Joinson, C., Ben-Shlomo, Y., \& Henderson, A. J. (2009). Mothers' anxiety during pregnancy is associated with asthma in their children. Journal of Allergy and Clinical Immunology, 123(4), 847-853.e11. https://doi.org/10.1016/j.jaci.2009.01.042

Ding, X. X., Wu, Y. Le, Xu, S. J., Zhu, R. P., Jia, X. M., Zhang, S. F., ... Tao, F. B. (2014). Maternal anxiety during pregnancy and adverse birth outcomes: A systematic review and metaanalysis of prospective cohort studies. Journal of Affective Disorders, 159(81), 103-110. https://doi.org/10.1016/j.jad.2014.02.027

DiPietro, J. A., Costigan, K. A., Nelson, P., Gurewitsch, E. D., \& Laudenslager, M. L. (2008). Fetal responses to induced maternal relaxation during pregnancy. Biological Psychology, 77(1), 11-19. https://doi.org/10.1016/j.biopsycho.2007.08.o o8

Fadzil, A., Balakrishnan, K., Razali, R., Sidi, H., Malapan, T., Japaraj, R. P., ... Manaf, M. R. A. (2013). Risk factors for depression and anxiety among pregnant women in Hospital Tuanku Bainun, Ipoh, Malaysia. Asia-Pacific Psychiatry, 5(SUPPL. 1), 7-13. https://doi.org/10.1111/appy.12036

Fazdria \& Harahap, M. S. (2016). Gambaran Tingkat Kecemasan Pada Ibu Hamil Dalam Menghadapi Persalinan Di Desa Tualang Teungoh Kecamatan Langsa Kota Kabupaten Kota Langsa Tahun 2014. Jurnal Kedokteran Syiah Kuala, 16(1), 6-13.

Glover, V. (2011). Annual research review: Prenatal stress and the origins of psychopathology: An evolutionary perspective. Journal of Child Psychology and Psychiatry and Allied Disciplines, $\quad 52(4), \quad 356-367$. https://doi.org/10.1111/j.1469-7610.2011.02371.X

Glover, V. (2014). Maternal depression, anxiety and stress during pregnancy and child outcome; What needs to be done. Best Practice and Research: Clinical Obstetrics and Gynaecology, 28(1), 25-35. https://doi.org/10.1016/j.bpobgyn.2013.08.017

Guszkowska, M., Sempolska, K., Zaremba, A., \& Langwald, M. (2013). Exercise or relaxation? Which is more effective in improving the 
emotional state of pregnant women? Human Movement, $\quad 14(2), \quad 168-174$. https://doi.org/10.2478/humo-2013-0020

Handayani, R., Fajarsari, D., Retno Trisna Asih, D., \& Naeni Rohmah, D. (2016). Pengaruh Terapi Murottal Al-Qur'an Terhadap Penurunan Intensitas Nyeri Persalinan dan Kecemasaan dalam Persalinan Primigravida Kala I Fase Aktif di RSUD Prof. Dr. Margono Soekardjo Tahun 2014. Jurnal Ilmiah Kebidanan, 7(1), 119129. Retrieved from http://ojs.akbidylpp.ac.id/index.php/Prada/a rticle/viewFile/147/135

Hasanjanzadeh, P., \& Faramarzi, M. (2017). Relationship between maternal general and specific-pregnancy stress, anxiety, and depression symptoms and pregnancy outcome. Journal of Clinical and Diagnostic Research, 11(4), VCo4-VCo7. https://doi.org/10.786o/JCDR/2017/24352.961 6

Hidayati, D. S. (2014). Latar Belakang Psikologis Kecemasan Ibu Hamil Usia 35 Tahun ke Atas. Cell, 3(4), 1-15. https://doi.org/10.1016/j.cell.2009.01.043

Huliana, M. (2001). Panduan Menjalani Kehamilan Sehat. Jakarta: Puspa Swara.

Jabbari, B., Mirghafourvand, M., Sehhatie, F., \& Mohammad-Alizadeh-Charandabi, S. (2017). The Effect of Holly Quran Voice With and Without Translation on Stress, Anxiety and Depression During Pregnancy: A Randomized Controlled Trial. Journal of Religion and Health, 1-11. https://doi.org/10.1007/s10943017-0417-x

Janiwarty, B., \& Pieter, H. Z. (2012). Pendidikan Psikologi Untuk Bidan. Medan: Rapha Publishing.

Kartono, K. (2007). Psikologi Wanita: Mengenal Wanita sebagai Ibu dan Nenek. Bandung: CV Mandar Maju.

Karyati, S., \& Kudus, S. M. (2016). ISSN $2407-9189$ The 4 th Univesity Research Coloquium 2016 APLIKASI TERAPI MUROTAL AL- QUR 'AN DAN KOMUNIKASI TERAPEUTIK ISSN 24079189 The 4 th Univesity Research Coloquium 2016. 175-182.

Kementerian Kesehatan RI. (2014). Situasi Kesehatan Ibu. Retrieved September 24, 2019, from www.depkes.go.id

Khashan, A. S., Wicks, S., Dalman, C., Henriksen, T. B., Li, J., Mortensen, P. B., \& Kenny, L. C. (2012). Prenatal stress and risk of asthma hospitalization in the offspring: A swedish population-based study. Psychosomatic Medicine, $\quad 74(6), \quad 635-641$.
https://doi.org/10.1097/PSY.obo13e31825ac5e7 Lee, A. M., Lam, S. K., Sze Mun Lau, S. M., Chong, C. S. Y., Chui, H. W., \& Fong, D. Y. T. (2007). Prevalence, course, and risk factors for antenatal anxiety and depression. Obstetrics and Gynecology, 110(5), 1102-1112. https://doi.org/10.1097/o1.AOG.0000287065.5 9491.70

Maimunah, A \& Retnowati, S. (2011). Pengaruh Pelatihan Relaksasi Dengan Dzikir Untuk Mengatasi Kecemasan Ibu Hamil Pertama. Psikoislamika : Jurnal Psikologi Dan Psikologi Islam, $8(1), \quad \mathbf{1 - 2 2 .}$ https://doi.org/10.1886o/psi.voi1.1543

Maimunah, S. (2009). Kecemasan Ibu Hamil Menjelang Persalinan Pertama. Jurnal Humanity, 5 (1)(1), 61-67.

Martínez, R. A. O., \& Castillo, A. (2016). Relación entre estrés durante el embarazo y nacimiento pretérmino espontáneo. Revista Colombiana de Psiquiatria, 45(2), 75-83. https://doi.org/10.1016/j.rcp.2015.07.006

Nekoee, T., \& Zarei, M. (2015). Evaluation the Anxiety Status of Pregnant Women in the Third Trimester of Pregnancy and Fear of Childbirth and Related Factors. British Journal of Medicine and Medical Research, 9(12), $\quad$ 1-8. https://doi.org/10.9734/bjmmr/2015/19784

Nevid, J. S., Rathus, S. A., \& Greene, B. (2018). Psikologi Abnormal Edisi Kelima Jilid 1. Jakarta: Erlangga.

Nurlailiyah, A., Machfoedz, I., \& Sari, D. P. (2016). Tingkat Pengetahuan Tentang Faktor Risiko Persalinan dengan Tingkat Kecemasan dalam Menghadapi Persalinan pada Ibu Hamil Trimester III di Puskesmas Sleman Yogyakarta. Jurnal Ners Dan Kebidanan Indonesia, $\quad 3(3), \quad 169$. https://doi.org/10.21927/jnki.2015.3(3).169-175

O'Connor, T. G., Heron, J., Golding, J., Beveridge, M., \& Glover, V. (2002). Maternal antenatal anxiety and children's behavioural/emotional problems at 4 years. Report from the Avon Longitudinal Study of Parents and Children. British Journal of Psychiatry, 180(JUNE), 502508. https://doi.org/10.1192/bjp.180.6.502

Payne, R. (2005). Relaxation Techniques (3rd ed). New York: Edinburgh.

Prapto, D. A. P., Nashori, F., \& Rumiani, R. (2015). Terapi Tadabbur Al-Qur'an Untuk Mengurangi Kecemasan Menghadapi Persalinan Pertama. Jurnal Intervensi Psikologi (JIP), $\quad 7(2), \quad$ 131-142. https://doi.org/10.20885/intervensipsikologi. vol7.iss2.art1 
Rinata, E., \& Andayani, G. A. (2018). Karakteristik ibu (usia, paritas, pendidikan) dan dukungan keluarga dengan kecemasan ibu hamil trimester III. Medisains, 16(1), 14 https://doi.org/10.30595/medisains.v16i1.2063

Rosario, M. K., Premji, S. S., Nyanza, E. C., Bouchal, S. R., \& Este, D. (2017). A qualitative study of pregnancy-related anxiety among women in Tanzania. BMJ Open, $7(8), \quad 1-8$. https://doi.org/10.1136/bmjopen-2017-016072

Schetter, C. D., \& Tanner, L. (2012). Anxiety, depression and stress in pregnancy: Implications for mothers, children, research, and practice. Current Opinion in Psychiatry, 25(2), 141-148. https://doi.org/10.1097/YCO.obo13e32835036 80

Shin, H. S., \& Kim, J. H. (2011). Music therapy on anxiety, stress and maternal-fetal attachment in pregnant women during transvaginal ultrasound. Asian Nursing Research, 5(1), 1927. https://doi.org/10.1016/S19761317(11)60010-8

Siallagan, D \& Lestari, D. (2018). Tingkat Kecemasan Menghadapi Persalinan Berdasarkan Status Kesehatan, Graviditas Dan Usia Di Wilayah Kerja Puskesmas Jombang. Jornal of Midwivery, 1(September), 104-110.

Silva, M. M. de J., Nogueira, D. A., Clapis, M. J., \& Leite, E. P. R. C. (2017). Anxiety in pregnancy: Prevalence and associated factors. Revista $\mathrm{Da}$ Escola de Enfermagem, 51, 1-8. https://doi.org/10.1590/S1980220X2016048003253

Staneva, A. A., Morawska, A., Bogossian, F., \& Wittkowski, A. (2018). Maternal psychological distress during pregnancy does not increase the risk for adverse birth outcomes. Women and Health, 58(1), 92-111. https://doi.org/10.108o/o3630242.2017.128239 5

Tarabulsy, G. M., Pearson, J., Vaillancourt-Morel, M. P., Bussières, E. L., Madigan, S., Lemelin, J. P., ... Royer, F. (2014). Meta-analytic findings of the relation between maternal prenatal stress and anxiety and child cognitive outcome. Journal of Developmental and Behavioral Pediatrics, 35(1), 38-43. https://doi.org/10.1097/DBP.ooooooooooooo 003

Teixeira, C., Figueiredo, B., Conde, A., Pacheco, A., \& Costa, R. (2009). Anxiety and depression during pregnancy in women and men. Journal of Affective Disorders, 119(1-3), 142-148. https://doi.org/10.1016/j.jad.2009.03.005
Toosi, M., Akbarzadeh, M., \& Ghaemi, Z. (2017). The Effect of Relaxation on Mother's Anxiety and Maternal-Fetal Attachment in Primiparous IVF Mothers. Journal of the National Medical Association, 109(3), 164-171. https://doi.org/10.1016/j.jnma.2017.03.002

Triasani, D., \& Hikmawati, R. (2016). Hubungan Kecemasan Ibu Hamil Terhadap Kejadian Preeklamsia Di RSUD Majalaya Kabupaten Bandung. Ilmiah Bidan, 1(3), 15-16.

Untari, M. M. \& R. F. A. (2016). Kecemasan Ibu Hamil Ditinjau dari Intensitas Membaca ALQur'an dan Kelompok Usia. Humanitas, 13(01), 13-21. https://doi.org/10.1017/CBO9781107415324.00 4

Utami, S. (2018). Angka Kematian Ibu dan Bayi Indonesia, 10 Negara Tertinggi di Dunia. Retrieved September 22, 2019, from https://mediaindonesia.com/

van den Heuvel, M. I., Johannes, M. A., Henrichs, J., \& Van den Bergh, B. R. H. (2015). Maternal mindfulness during pregnancy and infant socio-emotional development and temperament: The mediating role of maternal anxiety. Early Human Development, 91(2), 103-108.

https://doi.org/10.1016/j.earlhumdev.2014.12.0 03

van den Heuvel, Marion I., Donkers, F. C. L., Winkler, I., Otte, R. A., \& Van den Bergh, B. R. H. (2013). Maternal mindfulness and anxiety during pregnancy affect infants neural responses to sounds. Social Cognitive and Affective Neuroscience, 10(3), 453-460. https://doi.org/10.1093/scan/nsuo75

Ventura, T., Gomes, M. C., \& Carreira, T. (2012). Cortisol and anxiety response to a relaxing intervention on pregnant women awaiting amniocentesis. Psychoneuroendocrinology, 37(1), 148-156. https://doi.org/10.1016/j.psyneuen.2011.05.016

Vujovic, M., Sovilj, M., Plesinac, S., Rakonjac, M., Jelicic, L., Adamovic, T., \& Stokic, M. (2019). Effect of antenatal maternal anxiety on the reactivity of fetal cerebral circulation to auditory stimulation, and early child development. Srpski Arhiv Za Celokupno Lekarstvo, 147(5-6), 327-334. https://doi.org/10.2298/sarh181002024V

Wahida, S., Nooryanto, M., \& Andarini, S. (2015). Terapi Murotal Al-Qur' an Surat Arrahman Meningkatkan Kadar $\beta$-Endorphin dan Menurunkan Intensitas Nyeri pada Ibu Bersalin Kala I Fase Aktif Al Qur ' an Surah Arrahman Recital Therapy Increase $\beta$ - 
Endorphin Levels and Reduce Childbirth Pain Intensity on A. Jurnal Kedokteran Brawijaya, 28(3), 213-216.

World Health Organization. (2019). Maternal Mortality. Retrieved September 22, 2019, from https://www.who.int/news-room/factsheets/detail/maternal-mortality

Yang, M., Li, L., Zhu, H., Alexander, I. M., Liu, S., Zhou, W., \& Ren, X. (2009). Music therapy to relieve anxiety in Pregnant women on bedrest: A randomized Trial, controlled trial. MCN The American Journal of Maternal/Child Nursing, 34(5), 316-323. https://doi.org/10.1097/o1.NMC.0000360425. 52228.95

Zamriati, W. O., Hutagaol, E., \& Wowiling, F. (2013). ejournal keperawatan (e-Kp) Volume. 1 Nomor. 1 A gustus 2013. Ejournal Keperawatan $(e-K p), 1,1-7$. 